\title{
Technical Students' Perceptions and Motivations Towards Instructional Courseware on Construction Technology Course
}

\author{
Hanna Hayzalina Zainal ${ }^{1}$, Noorhidayu Mohd. Nordin ${ }^{1}$, Salihah Sombar Abdul Hamid ${ }^{1}$, \\ Nur Akmal Hassan ${ }^{2}$, Mohamad Hisyam Mohd. Hashim ${ }^{3}$ \\ ${ }^{1}$ Kolej Kemahiran Tinggi Mara (KKTM), Sri Gading, Johor, Malaysia \\ ${ }^{2}$ Sekolah Menengah Kebangsaan Bahau, Negeri Sembilan, Malaysia \\ ${ }^{3}$ Universiti Tun Hussein Onn Malaysia (UTHM), Johor, Malaysia
}

\author{
Email address: \\ hb130030@siswa.uthm.edu.my (H. H. Zainal), hb130031@siswa.uthm.edu.my (N. Mohd. Nordin), \\ hb130066@siswa.uthm.edu.my (S. S. A. Hamid), hb130046@siswa.uthm.edu.my (N. A. Hassan), \\ mhisyam@uthm.edu.my (M. H. Mohd. Hashim)
}

\section{To cite this article:}

Hanna Hayzalina Zainal, Noorhidayu Mohd. Nordin, Salihah Sombar Abdul Hamid, Nur Akmal Hassan, Mohamad Hisyam Mohd. Hashim. Technical Students' Perceptions and Motivations Towards Instructional Courseware on Construction Technology Course. International Journal of Vocational Education and Training Research. Vol. 2, No. 1, 2016, pp. 1-6. doi: 10.11648/j.ijvetr.20160201.11

\begin{abstract}
This article presents technical students' perceptions and motivations towards instructional courseware on Construction Technology course. Creative and innovative educators always do improve in upgrading their approach of teaching and learning. One of the approaches is by using instructional courseware. This is quantitative study incorporated survey strategy with four Likert scales questionnaire instrument involving 170 students focused on students' perceptions of instructional courseware and motivation of students after using the instructional courseware. Five elements of perception that have been assessed consist of the content, design of interactive, interface design, learning strategies and motivation towards this interactive courseware. The instructional courseware focuses on fundamental concepts of construction including the Site Preparation and Construction Components Clearing System. Each section includes content, graphics or videos pertaining and followed by quizzes that evaluate students' understanding. The mean value analyzed for student's perception towards instructional courseware exceeds 3.40 which show a good acceptance to the courseware developed. Motivation of students also assessed using a model of ARCS. For future studies, the effectiveness of this courseware should be evaluated by using pre and post-test.
\end{abstract}

Keywords: Instructional, Courseware, Perception, Motivation

\section{Introduction}

Technology is now expanding in any field. Technology developments give positive impact towards educational system as technology can facilitate and develop the students' understanding pertaining to certain topic which has been taught in class [1].

Nowadays, most of teachers are eager to integrate technology in their lessons in order to educate the students on information society. The information computer technologies (ICTs) are globally recognized tools that needs to be fully integrated in all educational fields especially Technical Vocational Education Technologies (TVET). Since TVET is considered the nature and sophisticated field to the economic, industrial and human resources development, in public or private sector [2]. The main activity of educating which are development of the learning module, delivery of teaching, learning and evaluation strengthening program supported by momentum growth of ICT [1].

The effective ICTs integration into TVET could change the entire focus of manpower needs in the world; from "skilled-based" to "ICT-Capable" work force. Therefore, the demand of an effective "ICT-based" TVET is not an over generalization. TVET, being one of the most distinguished fields of education right from Stone Age to the present era of industrial development, still maintain its tempo toward the infrastructural, industrial, human and material resources development [2].

Instructional courseware is introduced to enhance teaching 
and learning process as an initiative to improve positive impact toward student's achievement. At the same time it may create the smooth process of teaching and learning and attracted the interest of the students to learn the subject, with supported by some questions for revision in the form of self-assessment [1]. Further add that tools like this instructional courseware provide formative evaluation of the end product and individual reflection on learning [3].

This study was conducted to determine technical students' perceptions and their motivation towards instructional courseware on Construction Technology course. In technical courses, hands-on learning is a priority in enhancing students' understanding. This approach should be supported with the other learning strategies to ensure that the students really understand the fundamental concept of construction. The courseware is an added value to the meaningful teaching and learning process that can be delivered in a very interactive and interesting approach. It also provides motivation and inspiration to explore of the real construction situation in Malaysia. Researches indicate that active, reflective, intuitive and high visual students benefit creatively after using the multimedia learning tool [4].

This courseware is developed based on tutorial learning approach. Tutorial learning approach allows individual learning on the lesson content supported with the quizzes in a sequential and orderly method. Tutorial generally adopts the first two approaches which are the way of delivering the course contents and helping the students in the initial process of getting that content [5].

Tutorial strategy introduced and described the skills, new information, and thus supervise students' attempt to apply what they have learned. Tutorial strategy is worked based on students' response and if they forgot previous learning, they can choose to repeat any necessary learning. Meanwhile, for the certain effective group of students, they can pursue their studies to a next level. This strategy provides an opportunity for the students to learn based their own pace irrespective to the level of student achievement [6].

Application of this effective use of interactive courseware is mainly to help students with various learning styles. The use of computer technology through a combination of multimedia elements such as text, graphics, animation, audio and video allows students to learn certain concepts quickly, keeping the memory more longer, providing a clearer picture and accelerate student understanding [7]. Technological developments affect the structure and function of educational institutions. Educators also acknowledged the significance to integrate technology into their teaching process in educating the students on informational literate [8].

Animations are embedded in the development of interactive courseware. It can be considered as teaching aids through multimedia [9]. Animation can stimulate students' interest. The use of graphic animation courseware can be implemented to students with different cognitive styles and abilities of visual spatial abilities[10]. According to [11], the animated enhance cognitive processes in providing a clear picture that will reduce the need to process information, and memorizing techniques. Pedagogical multimedia courseware will generate magnetic force students to their learning process [12]. That means the vision, focus, soul and mind are actively focused on learning. Therefore, with the focus entirely on the learning process, it is undeniable that learning courseware is useful in helping the educators to achieve objectives outlined and improve students' learning. Construction Technology courseware is multimedia courseware that perfectly influence students learning by motivation since the perceptions students towards courseware is positively interesting.

\section{Related Works}

\subsection{Motivation}

Motivation is categorized as intrinsic and extrinsic motivation. Extrinsic motivators are independent of the instruction, such as paying learners or otherwise offering learners rewards they consider desirable. However the use of extrinsic motivators is being arguing among researchers since the goals becomes the reward rather than learning [5]. Intrinsic motivator is intrinsically motivation if learners consider it to be interesting. Alessi and Trollip point out several techniques to enhance intrinsic motivation which is (i) use game techniques, (ii) use embellishments such as visual techniques to increase of work and attention and to encourage deeper cognitive processing, (iii) use exploratory environments, (iv) give the learner personal control, (v) challenge the learner, (vi) arouse the learner's curiosity and (vii) give encouragement even when the errors are made.

Techniques for maintaining motivation should be considered at both the macro and micro level. The macro-level refers to the instructional strategy such as using courseware in learning. The micro level refers to specific elements of a lesson, such as using graphics and animation. Based on the criteria of intrinsic motivations it's obviously stated that using a courseware multimedia in construction technology is one of the way to enhance students' motivation on learning technical and vocational education. This courseware also contains the elements of multimedia such as video. Teaching materials with supplementary video clips may improve lecture organization and presentation in order to achieve effective teaching and learning [13]. The video material use in learning is to increase student's attention and increase learning quality. There are two important goals should be achieved in process of learning, there are reducing cognitive load and increasing student's attention [13].

One of the advantages of computerized animation is it able to clarify and simplify dynamic information to students There were several researches summed out effectiveness of computerized animation in deliver information, commentate abstracted concepts, draw attention, increase interest and motivation, neutralize dangerous or sensitive subjects and present complex information in little time [12].

The quality of education is affected, when lack of learning motivation. In this sense, learning motivation is inseparable 
from learning effectiveness: greater motivation improves learning results and encourages learners to make a greater effort and continue learning [14].

\section{2. $A R C S$}

The ARCS Model of Motivational Design is a well-known and widely applied model of instructional design. It is simple and powerful because is rooted in a number of motivational theories and concepts. This ARCS Model is an easy-to-apply, heuristic approach to increasing the motivational appeal of instruction. Following its development, the ARCS Model was field tested in two in-service teacher education programs. Based on the results of these field tests, the ARCS Model appears to provide useful assistance to designers and teachers, and warrants more controlled studies of its critical attributes and areas of effectiveness.

The ARCS Model of motivation was developed in response to a desire to find more effective ways of understanding the major influences on the motivation to learn, and for systematic ways of identifying and solving problems with learning motivation. The resulting model contains a four category synthesis of variables that encompasses most of the areas of research on human motivation, and a motivational design process that is compatible with typical instructional design models. The four elements of motivation refer to ARCS Model are attention, relevance, confidence and satisfaction.

\subsubsection{Attention}

Attention refers to the response of students to start learning by teaching materials. Startup software attractive and effective courseware to students will increase students' attention. In prepared an instructional courseware, variety content, elements, colours and attractive presentation is applied. It's for captured the attention when stating using lesson and maintain the attention till the end. Attention is strategies for arousing and sustaining curiosity and interest [15].

Attention is based on two types of arousal that is perceptual arousal and inquiry arousal. Perceptual arousal affords novelty, surprise, incongruity or uncertainty, such as a teacher places a sealed box covered with question marks on a table in front of the class. This situation will attract students focus on the lesson. Inquiry arousal is the stimulate curiosity by posing questions or problems to solve, example a teacher presents a scenario of a problem situation and asks the class to brainstorm possible solutions based on what they have learned in the lesson. Another element to attract student attention is variability, such as incorporate a range of methods and media to meet students' varying needs. As an example, after teacher teaches the concepts, ask students to form a groups and assigns each group a set of practice problems [15].

The courseware that has been prepared is applied with the element of construction as the layout and the colour using for the layout is interesting and attracted. The courseware is included a montage to give students view the whole topics in the courseware. The elements multimedia that is applied in the courseware could also attract students' attention. Figure 1 shows the first interactive slide introduces the overall overview of the course with the support of an audio.

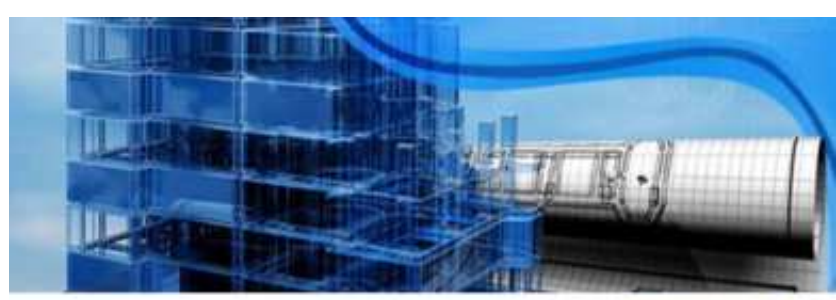

\section{CONSTRUCTION TECHNOLOGY}

Computer Based Tutorial START

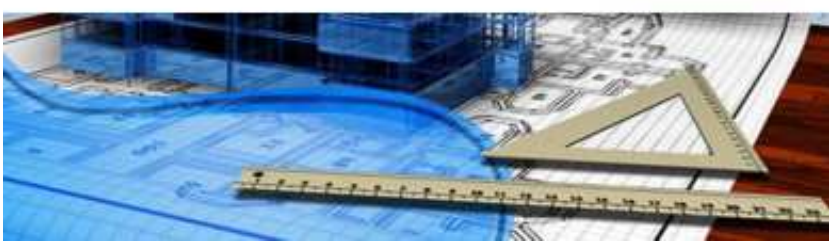

Figure 1. First slide of instructional courseware.

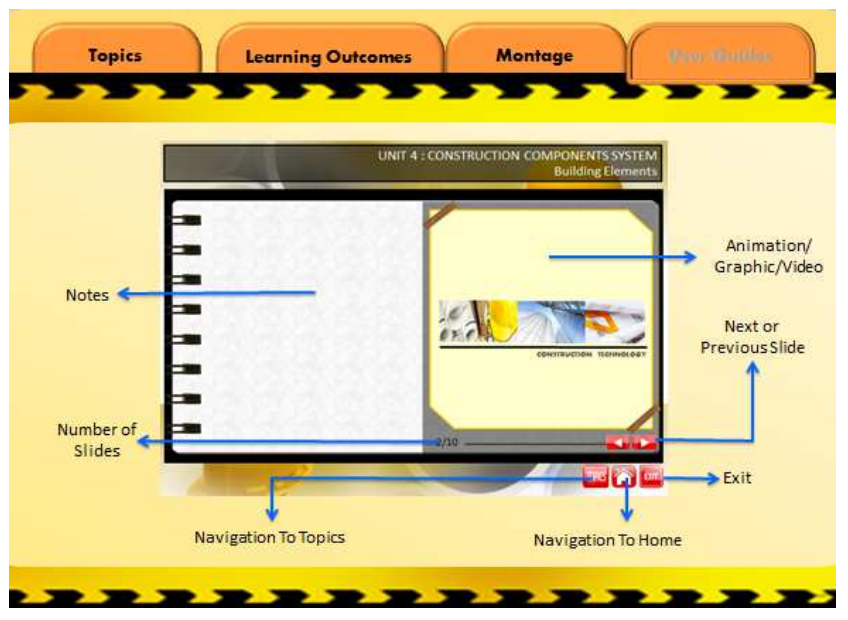

Figure 2. User guide slide.

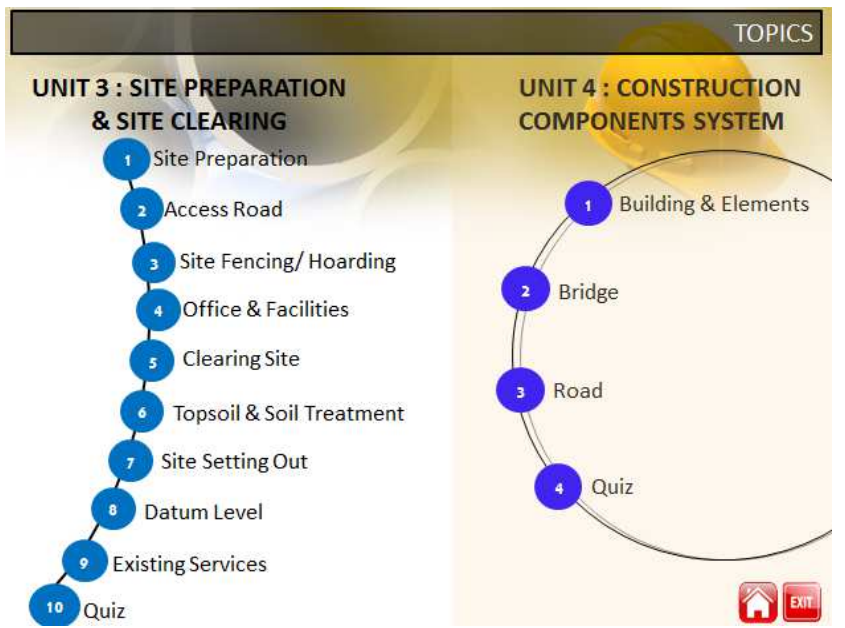

Figure 3. Specific sub-topic. 


\subsubsection{Relevance}

Relevance will help students link the existing knowledge with new knowledge. It helps students understand the knowledge and application of knowledge and skills in the future. Increased relevance could this happen when the relationship with students' prior knowledge related to the construction of new experiences using the instructional courseware. Relevance reflects on the strategies that link to learners' needs, interests, and style. Relevance includes elements of goal orientation, matching and familiarity. This courseware includes a user guide slide to guide the students to explore the instructional courseware as shown in Figure 2. Figure 3 shows specific sub-topic for student to freely explore.

Goal orientation presents the objectives and useful purpose of the instruction and specific methods for successful achievement such as explains the objectives of the lesson.

Motive matching is matched objectives to student needs and motives that mean teacher allows students to present their projects in writing or orally to accommodate different learning needs and styles.

Familiarity is present content in ways that are understandable and that are related to the learners' experience and values as example teacher let the students to provide examples from their own experiences for the concept presented in class [15].

Courseware construction technology is fulfilled the relevance elements since its using tutorial concepts to let student freely explore the courseware based on their personal performance. Excellent or moderate students could operate based on their attention and the layout for notes and quizzes is consistent provide familiarity to student.

\subsubsection{Confidence}

Confidence is emphasizing positive values towards their activities. There are three elements to encourage students' confidence that are learning requirements, success opportunities and personal responsibility.

Learning requirements means let students alert their learning and performance requirements and assessment criteria by providing them a list of assessment criteria for their research projects and circulates examples. Success opportunities are provide challenging and meaningful opportunities for successful learning such as allow the students to practice extracting and summarizing information from various sources and then provides feedback before the students begin their research projects. Personal responsibility is link learning success to students' personal effort and ability such as teacher provides written feedback on the quality of the students' performance and acknowledges the students' dedication and hard work [15]. Students enhanced their confidence level during exploring the instructional courseware. Figure 4 below shows a slide that contain notes and supported by related pictures that enhanced confidence level of the students.

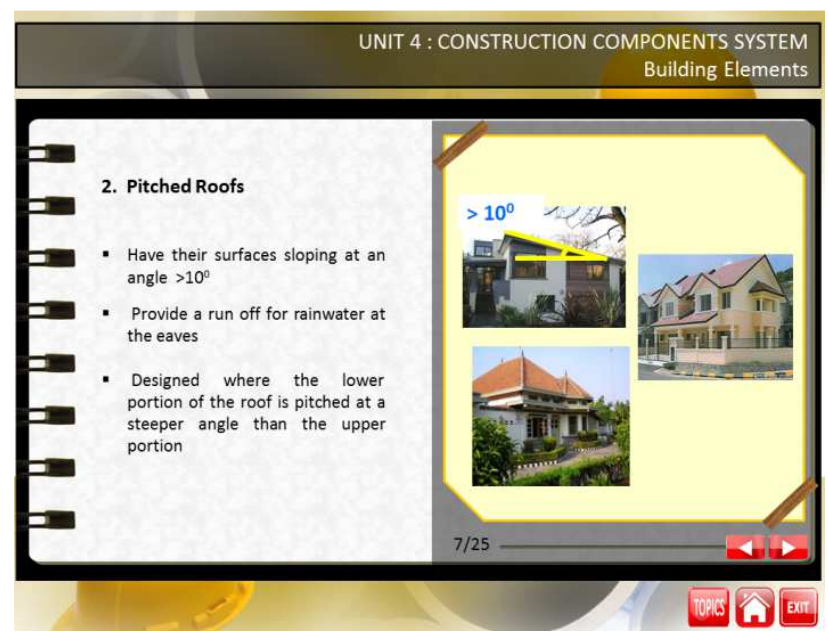

Figure 4. The content slide.

This instructional courseware is also embedding the soft skill to the technical students through specific activities in classroom or outside classroom. The skills are self-adaptability skill, planning and decision making skill. The intended soft skills which refer to a combination of knowledge and skills need to be applied in meeting the requirements of the industry [16]. As the fundamental of construction can be found in the instructional courseware, the students that use the courseware can also be said will obtained soft skill via the courseware. The soft skill that is unconsciously embedded in the courseware will help the students to grasp the generic skill needed in the real situation of construction beyond their classroom.

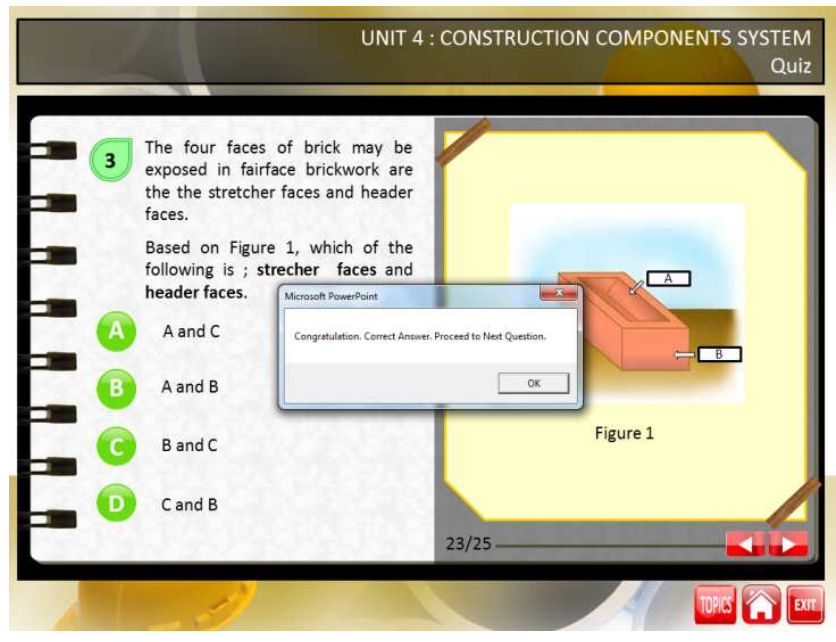

Figure 5. The slide of quizzes.

\subsubsection{Satisfaction}

Satisfaction is achieved once students can practice their knowledge and skills and they receive good response to continue learning. For satisfaction there are two reinforcements. The first one is intrinsic reinforcement means encourage and support intrinsic enjoyment of the learning experience. Example a teacher invites former students to provide testimonials on how learning these skills helped them with subsequent homework and class projects. Extrinsic 
rewards is provide positive reinforcement and motivational feedback such as a a certificates to students as they master the complete set of skills. Figure 5 shows a slide of the courseware that provides quizzes with feedback to encourage and make the students satisfy with their performance.

Satisfactions also filled by equity which are maintain consistent standards and consequences for success. As an example, after the term project has been completed, the teacher provides evaluative feedback using the criteria described in class. [15]. The construction technology courseware is also provides student satisfaction by all the elements multimedia that are using in the courseware.

\section{Methodology}

This study incorporated quantitative research methodology with survey strategy with four Likert scales questionnaire instrument to evaluate the effectiveness in terms of the functional of the interactive courseware. The sample of the study consists of 170 technical students in Construction Technical College with the range age 18-23 years old. The students were introduced with the Construction Technology interactive courseware and questionnaire will be given right after they have completed in exploring the courseware. The questionnaire given comprises of five parts which are (i) analysis the content in the interactive courseware, (ii) analysis on the design of the interactive courseware, (iii) analysis on the interfaced of the interactive courseware, (iv) analysis on the learning strategies or approaches used in the interactive courseware and (v) motivation towards this interactive courseware. These data were analyzed by using Statistical Packages for Social Sciences (SPSS).

\section{Finding and Discussions}

Table 1. The Instructional Courseware.

\begin{tabular}{ll}
\hline Instructional Courseware & Mean \\
\hline Content & 3.43 \\
Interaction & 3.40 \\
Interface & 3.48 \\
Learning Strategies & 3.48 \\
\hline
\end{tabular}

This part of questionnaire is an early overview by the students about the courseware, the students' preference about the appearance of the courseware, in term of the design, interface and also the content an learning strategies used in the delivering the knowledge. Even this part of evaluation might always be neglected, the importance of the approach, design and procedure [17] is important in early evaluating any courseware used in instructional. The data abstracted via the questionnaires given to the students reveals that they enjoy the courseware very much as mean of the four component of the instructional courseware; content, design, interface and learning strategies are 3.43, 3.40, 3.48 and 3.48 respectively.

This showed that the students find the courseware is really helpful when it comes to help them in understanding the content of the subject and its' interface really enjoyable and they are not bored by it. Besides that, learning strategies used in the courseware really suitable with the students' level this helps them to understand the content of the courseware. The lowest mean among four elements is interaction between the courseware and the students. It is because the constraints felt by the students when exploring the courseware without referring the user guide.

Table 2. Motivation.

\begin{tabular}{ll}
\hline Aspect & Mean \\
\hline Attention & 3.38 \\
Relevance & 3.36 \\
Confidence & 3.34 \\
Satisfaction & 3.40 \\
\hline
\end{tabular}

Kellers' ARCS Model which focuses on creating, stimulating and motivational environment, has been research and adopted in various studies [18], thus the motivation of using the courseware also measured via the questionnaire, and the mean of four elements of motivation gained. Overall mean of the motivations elements is high because the courseware fulfilled the ARCS motivations elements.

For attention, with the mean is 3.38 proved that the courseware really catch the students' eye throughout their usage of the courseware. [18] For attention, not only the courseware has to catch the student eyes, but to maintain their interest throughout the learning process using the courseware is really important in this element. The courseware has to able to stimulate and arouse sufficient inquiry in the student to be able them to explore the knowledge in the courseware. These are the attention element in the courseware that makes the students pay their attention through the courseware.

The relevance of a courseware is about how the courseware aligned with the goal or aim of the students about the subject; whether the courseware meet the students' needs and how close the content of the courseware to the real situation faced by the students [19]. For this element, with mean of 3.36 suggested that the courseware relevant to the students', in term of their aims and goals in the subject, and the content of the courseware not alien to them, in the context of familiarity of content to the students.

The confidence elements of the courseware emphasized about success expectation, success opportunity and personal responsibility of the students [18] while using the courseware. The confident built in the students in the early stage of using the courseware, when there is a student guide to guide them for the first time student, then the confidence built throughout the courseware by a good organization structure from easy to hard, in the content expect. The students feel more confident as not only they are familiar with the content, but also the amount of knowledge delivered to them is sufficient and suitable for them, and not a burden for them to understand the courseware and the knowledge itself.

In satisfaction element, where intrinsic motivation [18] and 
positive consequences [19] is measured, stirred the students' satisfaction while using the courseware. With the mean 3.40, is a proof that the courseware is a satisfaction for the student, and bring positive feelings to the student, when using the courseware.

\section{Conclusion and Recommendation}

The content of instructional courseware focused on the critical basic part of Construction Technology. It compiled with interactive, informative and presentative of teaching strategies design will help students to understand the content. The findings of the analysis of user acceptance prove that the courseware Construction Technology successfully meet the needs and suit the target groups. This interactive instructional courseware is able to improve student motivation. This alternative of approach of teaching and learning strategy was accepted positively by students. This instructional courseware also contributes to the enhancement of students' understanding in the construction field, which considered difficult in the beginning of study. For future studies, the effectiveness of this courseware should be evaluated by using pre and post-test.

\section{Acknowledgements}

We express our deep sense of gratitude to the technical students of Kolej Kemahiran Tinggi MARA Sri Gading for data acquisition and feedback of the courseware.

We acknowledge with thanks the kind of patronage that we received from our lecturer for his guidance, suggestion and very constructive criticism.

\section{References}

[1] M. H. M. Hashim, "Using Technology and Instructional E-Material among Technical Teacher and Student into Teaching and Learning: A Qualitative Case Study," Int. Educ. Stud., vol. 8, no. 3, pp. 175-181, 2015.

[2] M. S. Saud, B. Shu'aibu, N. Yahaya, and M. A.-M. Yasin, "Effective integration of information and communication technologies (ICTs) in technical and vocational education and training (TVET) toward knowledge management in the changing world of work," AFRICAN J. Bus. Manag., vol. 5, pp. 6668-6673, 2011.

[3] M. H. M. Hashim, "Group blogs as toolkits to support learning environments in statistics subject: A qualitative case study," Int. Educ. Stud., vol. 5, no. 3, pp. 199-204, 2012.

[4] H. Kassim, "The Relationship between Learning Styles, Creative Thinking Performance and Multimedia Learning Materials," Procedia - Soc. Behav. Sci., vol. 97, pp. 229-237, Nov. 2013.
[5] S. M. Allesi and S. R. Trollip, Alessi, S. M., \& Trollip, S. R. (2001), 3rd Editio. United States of America: A Pearson Education Company, 2001.

[6] Z. H. Zaini, W. Fatimah, and W. Ahmad, "A Study on Students , Motivation in Learning Mathematics using Multimedia Courseware," pp. 7-9, 2010.

[7] H. Embong, "Pembinaan dan keberkesanan penggunaan perisian multimedia elektrokimia dalam pengajaran dan pembelajaran kimia tingkatan 4," Universiti Pendidikan Sultan Idris, 2005.

[8] B. Turan, "The Opinions of Teachers on the Use of Cartoon Character in the Mathematics Lesson," Procedia - Soc. Behav. Sci., vol. 141, pp. 1386-1391, Aug. 2014.

[9] R. E. Mayer and R. Moreno, "Aids to computer-based multimedia learning," Learn. Instr., vol. 12, no. 1, pp. 107-119, 2002.

[10] A. R. Madar and Y. Buntat, "The Effect of Using Visual Graphics via Interactive Multimedia on Learning of Mathematics (Straight Line) At Secondary School," vol. 3, no. September, pp. 94-103, 2011.

[11] L. P. Rieber and A. S. Kini, "Theoretical foundations of instructional applications of computer-generated animated visuals," J. Comput. Based Instr., vol. 18, no. 3, pp. 83-88, 1991.

[12] A. R. Madar and M. N. Hashim, "Effectiveness of Using Graphic Animation Courseware For Students With Different Cognitive Styles And Spatial Visual Abilities," vol. 3, no. 1, pp. $47-58$.

[13] M. Ljubojevic, V. Vaskovic, S. Stankovic, and J. Vaskovic, "Using supplementary video in multimedia instruction as a teaching tool to increase efficiency of learning and quality of experience," Int. Rev. Res. Open Distance Learn., vol. 15, no. 3, pp. 275-291, 2014.

[14] Y. - K. Juan and T. - W. Chao, "Game-Based Learning for Green Building Education," Sustainability, vol. 7, no. 5, pp. 5592-5608, 2015.

[15] J. Keller, "Motivation in Motivation in Instructional Design," Perform. Instr., vol. 26, no. 8, pp. 1-7, 1987.

[16] Mohamad Hisyam Mohd. Hashim. The Practice of Employability Teamwork Skills. International Journal of Vocational Education and Training Research. Vol. 1, No. 2, 2015, pp. 16-21. doi: 10.11648/j.ijvetr.20150102.11.

[17] P. Hubbard, "An integrated framework for CALL courseware evaluation," CALICO J., vol. 6, no. 2, pp. 51-72, 1988.

[18] J. Lee and Y. Kim, "Development of Web-based Courseware Applied ARCS Model," Int. Mag. Adv. Comput. Sci. Telecommun., vol. 3, no. 1, pp. 33-43, 2012.

[19] H. Tsukamoto, Y. Takemura, H. Nagumo, A. Monden, and K. Matsumoto, "The effects of teaching material remediation with ARCS-strategies for programming education," 2013 IEEE Front. Educ. Conf., pp. 717-723, 2013. 